[農化 第 41 巻, 第 10 号, p. 512 520, 1967]

$$
\text { シュロ種子のロイコアントシアンについて }
$$

水野卓, 鵜野 秋 実

(静岡大学農学部)

昭和 42 年 4 月 24 日受理

\title{
Leucoanthocyanins in the Seed Testa of Hemp-Plam, Trachycarpus Fortunei Wendl
}

By Takashi Mizuno and Akimi UNo

Department of Agricultural Chemistry, Faculty of Agriculture, Shizuoka University, Iwata

The polyphenolic substances contained in the testa of hemp-plam seeds were fractionated into five fractions as shown in Fig. 1, and three types of leucoanthocyanins, L-1, L-3 and $\mathrm{L}-4$, were isolated from them as main constituents.

L-1: was isolated from fraction 1 in Fig. 1 as the methanol-soluble, acetic acid-insoluble constituent, yield $2.96 \%$ of dried seed-testa. The amorphous powder obtained was soluble in methanol, ethanol and water in hot condition, but insoluble in ethyl acetate, acetic acid, acetone, ethyl ether and chloroform. m. p. $>325^{\circ} \mathrm{C}$ (decomp.), $[\alpha]_{\mathrm{D}}^{25}+46.9^{\circ}$ (in methanol). $\lambda_{\mathrm{max}}^{\mathrm{MeOH}} 281 \mathrm{~m} \mu, \lambda_{\mathrm{mln}}^{\mathrm{MeOH}} 262 \mathrm{~m} \mu$. Its acetate showed $[\alpha]_{\mathrm{D}}^{21}+50.9^{\circ}$ (in acetone), $\mathrm{CH}_{3} \mathrm{CO}$ content $28.26 \%$. In the products of dilute hydrochloric acid or sulfuric acid hydrolysis were detected cyanidin $\left(\lambda_{\mathrm{max}} 546 \mathrm{~m} \mu\right)$ and catechins mixture, probably (-)epicatechin, (-)-epicatechin gallate, $(+)$-catechin or gallic acid, and, in addition, consi derable amounts of phlobaphene-like substances.

L-3 : was isolated from fraction 3 by methanol extraction, precipitation with acetic acid, yield $0.07 \%$, m. p. $>251^{\circ} \mathrm{C}$ (decomp.), $[\alpha]_{\mathrm{D}}^{26}+138.4^{\circ}$ (in methanol). $\lambda_{\max }^{\mathrm{MeOH}} 285 \mathrm{~m} \mu, \lambda_{\mathrm{min}}^{\mathrm{MoOn}}$ $249 \mathrm{~m} \mu$. Acetate of L-3 was $[\alpha]_{\mathrm{D}}^{21}+152.3^{\circ}$ (in acetone), $\mathrm{CH}_{3} \mathrm{CO}$ content $40.78 \%$. Purified L-3 yielded predominantly cyanidin $\left(\lambda_{\mathrm{max}} 545 \mathrm{~m} \mu\right)$ as anthocyanidin and much smaller amount of phlobaphene substances, when heated with $2 \mathrm{~N}$-sulfuric acid.

L-4 : was isolated from fraction 4 in similar procedures, yield $0.61 \%, \mathrm{~m} . \mathrm{p} .>218^{\circ} \mathrm{C}$ (decomp.), $[\alpha]_{\mathrm{D}}^{2 \sigma}+86.1^{\circ}$ (in methanol), $\lambda_{\max }^{\mathrm{MeOH}} 278 \mathrm{~m} \mu, \lambda_{\min }^{\mathrm{MeOH}} 253 \mathrm{~m} \mu$. Acetyl derivative of L-4 showed $[\alpha]_{D}^{21}+85.2^{\circ}$ (in acetone), $\mathrm{CH}_{3} \mathrm{CO} 44.54 \%$. Cyanidin $\left(\lambda_{\max } 547 \mathrm{~m} \mu\right)$ and $33.8 \%$ of glucose were identified as the acid hydrolysis products of the purified $\mathrm{L}-4$.

These results indicate that leucocyanins of various types are contained in the testa of hemp-plam seeds ; L-1 is the condensed polymer hetero-type, L-3 is monomer or oligomer homo-type, and $\mathrm{L}-4$ is the glucoside type leucocyanine, respectively.

(Received April, 24, 1967)

シュロ ( ジュロ, Trachycarpus Fortunei Wendl) はヤシ科属する本邦原産の酎寒性の強い常粶の喬木で,

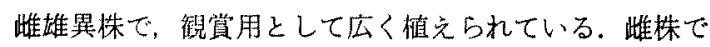
は初夏儿開花し晚秋に白粉をから゙る黒藍色の腎葴状球形 の漿果をつける，その䡚子の成分研究としては肧乳にマ ンナンの存在が指摘されている(1)程度で，はかに見るべ き研究はない。
ロイコアントシアン(プロアントシアンとも呼ばれる) は，それ自体は無色であるが，酸と加熱することによ。 て赤色のアントシアニジンを生成する化含物の総称で, フラン゚ン-3,4-ジオール誘導体またはその配稦体で，こ の他ポリフェノール成分との縮合型重合体多含めてい る(10). 各種植物の果奏, 花, 葉, 心材などに広く分布し ていて, 生化学的にはアントシアン, フラボノール, リ 
グニンなどの前駆物質として興味が持たれ，また食品の 渋味や変色に関与する成分として注目されてきている.

シュロ種子(特に種皮部) む, 塩酸一イソアミルアルコ ール反応が強陽性で，ロイコアントシアンの存在を知り， 分別法によってその種類と形態をしらべ，ロイコシアニ ジンとその配糖体ならびに縮合型重合体が主体であるこ とを明らかにしたので報告する。

実験および結果

\section{1. 供試シュロ種子}

岐阜県産 $(1964,1965$ 年) と静岡県産 (1966 年) の完 熟したワジュロ漿果 (Photo. 1) を採集して種子だけと 乙, $80^{\circ}$ 以下で通風乾燥後, 乳錰あるいは粉砕機で粗砕 乙, 篩分けと風選によって肧乳部之種皮部に分け，それ それをさらに粉砕し供試料とした。

シュロ種子の一般化学組成は Table I のようである. なお，全種子の成分含量は肧乳部と種皮部の分析値か ら重量比を加味して算出した值である.

\section{2. ポリフェノール成分の分別}

胚乳部に比べ種皮部がポリフェノール成分含量が高い

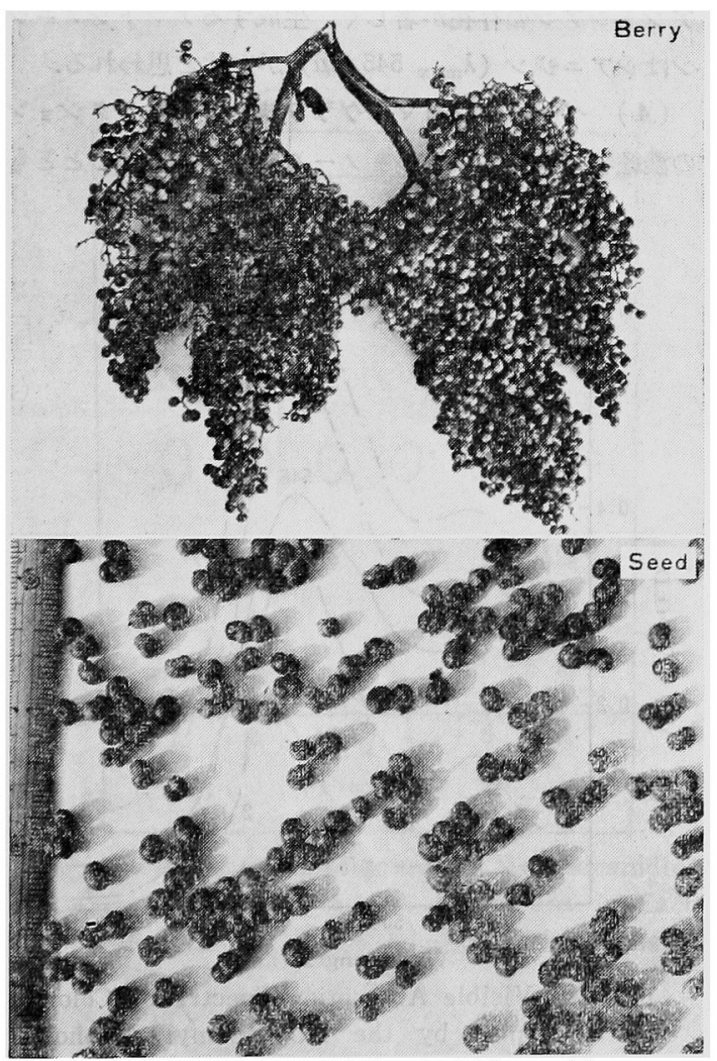

Photo, 1. Berry and Seed of Hemp-Plam.
TABLE I. Chemical Composition of the HEMP-PLAM SEED

( $\%$ for dry matter)

\begin{tabular}{lccc}
\hline & Endosperm & Testa & Whole Seed \\
\hline (Weight ratio) & 83.3 & 16.7 & 100 \\
Crude ash & 1.56 & 2.16 & 1.66 \\
Crude protein & 4.44 & 4.66 & 4.47 \\
Crude fat & 1.65 & 2.35 & 1.77 \\
Crude fiber*1 & 37.60 & 45.26 & 38.88 \\
Nitrogen-free extract*2 & 54.75 & 45.57 & 53.22 \\
Pentosan & 0.58 & 2.72 & 0.93 \\
\hline
\end{tabular}

*1 Main constituent was a mannan, because that yielded large amount of mannose when hydrolysed with $5 \%$ sulfuric acid at $130^{\circ} \mathrm{C}, 4 \mathrm{~atm}$.

*2 Main product by the acid hydrolysis was almost mannose.

ので，主に種皮部について検索を行なった。まず，熱 80\%エタノールで全ポリフェノール成分を抽出し，抽 出液からエタノールを留去することによって沈殿する縮

Powdered seed testa $200 \mathrm{~g}$

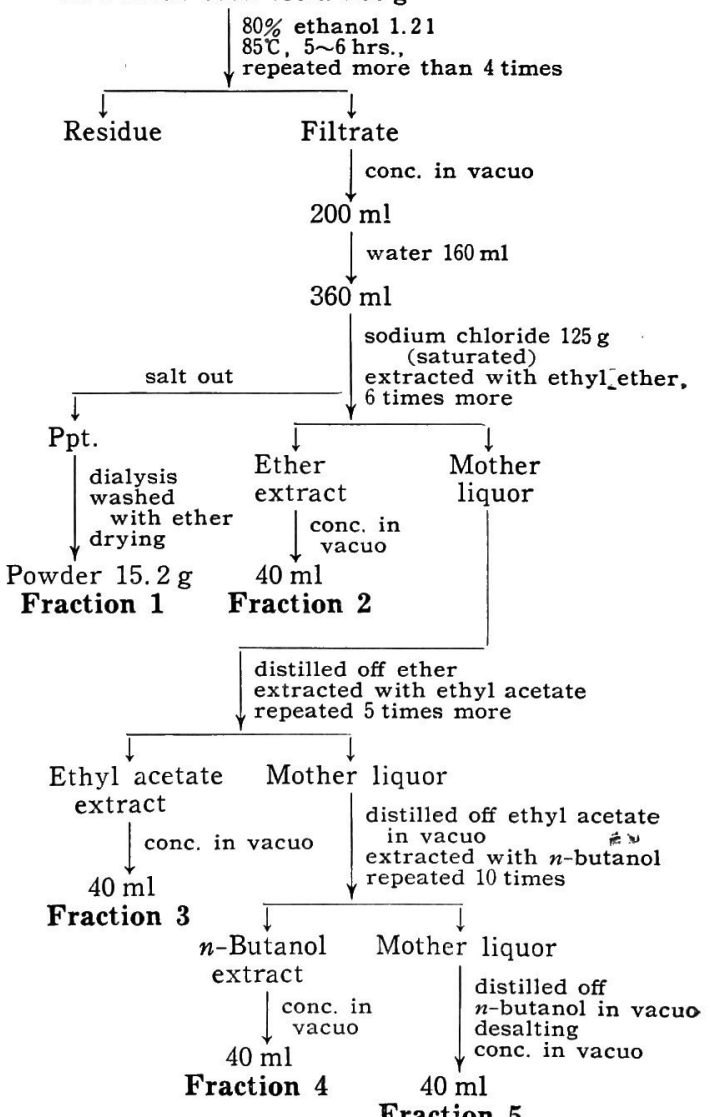

Fig. 1. Fractionation Procedure of Polyphenolic Components. 
合型重合体を塩析によって完全に分離し，その濾液をさ らКエーテル，酶酸エチル，n-プタノールて順次完全に 抽出することによってポリフェノール成分の分别を実施 し，フラクション1〜5を得た，実施例を Fig. 1 に示 した、な执,フラクション1は粉末とし、フラクション 2〜5 は定容の溶液あるいは粉末としてから以下の実験 を進めた。

3. ポリフェノール成分の検索

（1） 定性反応： 既報 ${ }^{(2)}$ に従って，各フラクション

TABle II. Detection of Polyphenolic COMPONENTS

\begin{tabular}{|c|c|c|c|c|c|}
\hline \multirow{2}{*}{ Reagents } & \multicolumn{5}{|c|}{ Fraction } \\
\hline & 1 & 2 & 3 & 4 & 5 \\
\hline $\mathrm{FeCl}_{3}$ solution & $H$ & + & H & $H$ & + \\
\hline Precipitation with $\mathrm{HCl}$-formalin & + & + & H & + & - \\
\hline Pb-acetate $\left\{\begin{array}{l}\text { Precipitability } \\
\text { Color (yellow) }\end{array}\right.$ & \pm & $\overline{-}$ & $\begin{array}{l}+ \\
+\end{array}$ & $\begin{array}{l}H \\
\pm\end{array}$ & H \\
\hline 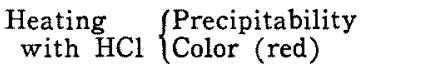 & $H$ & $\begin{array}{l} \pm \\
\pm\end{array}$ & + & H & \pm \\
\hline $\mathrm{NaOH}$ solution & \# & + & H & + & + \\
\hline $\mathrm{Zn}-\mathrm{HCl}$ reaction & - & - & $\pm ?$ & $\pm ?$ & - \\
\hline $\mathrm{HCl}$-isoamyl alcohol reaction & $H$ & H & \# & \# & $H$ \\
\hline Vanillin- $\mathrm{HCl}$ reaction & + & $H$ & 井 & $H$ & \pm \\
\hline Diazo reagent & Ht & + & H & H & H \\
\hline Fehling reagent & + & \pm & + & \pm & H \\
\hline
\end{tabular}

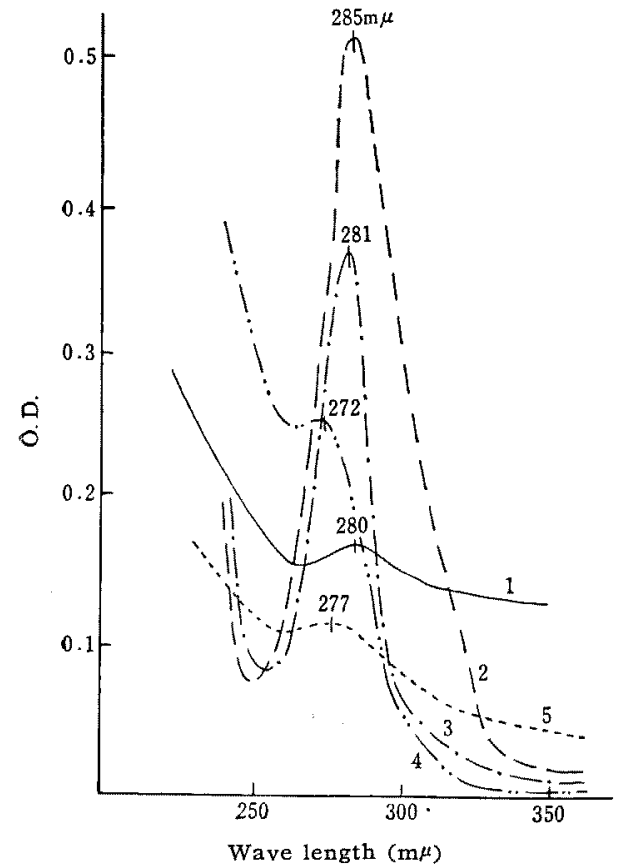

Fig. 2. UV-Absorption Spectra of Each Fraction.
について行なったタンニン, フラポノイド, ロイコアン トシアン、糖類などの定性反応の結果は Table II のよ らである、これらからシニロ種子(種皮部) のポリフェ ノール成分としては，ロイコアントシアンとカテキンの 存在が強陽性であるが，フラボノールの存在は微弱であ 乃.

（2）紫外部吸収スヘクトル： 各フラクションを, それの抽出に用いた糺溶媒に溶かし，日立製分光光度計 $S_{12}$-B 型で測定し Fig. 2 の結果を得た.これらの結果 もロイコアントシアンとカテキン類の存在を暗示してい る.

(3) 可視部吸収スベクトル： ロイコアントシアニ ジンの検索を目的に, 各フラクションについて塩酸ーイ ソアミルアルコール試駼 ${ }^{(3)}$ (試料の 50 倍容の $2 \mathrm{~N}$-塩酸・ イソフミルフルコール等容混液とともに $100^{\circ}, 20$ 分加 熱)を行ない, 生成するアントシアニジン・クロリドの 赤色液 (イソアミルフルコール夜) を適宜稀秎して，そ れらの可視部吸収スペクトルを測定し Fig. 3 の結果を 得た.すなわb，とくにフラクション $1,3,4$ にロイ二 アントシアンの存在が著しく, 生成するアントシアニジ ソはシアニジン $\left(\lambda_{\max } 545 \mathrm{~m} \mu\right)$ が主体と思われる.

(4) ペーパークロマトグラフ法： 各フラクション の濃紑物についてポリフェノール成分を検索するととる

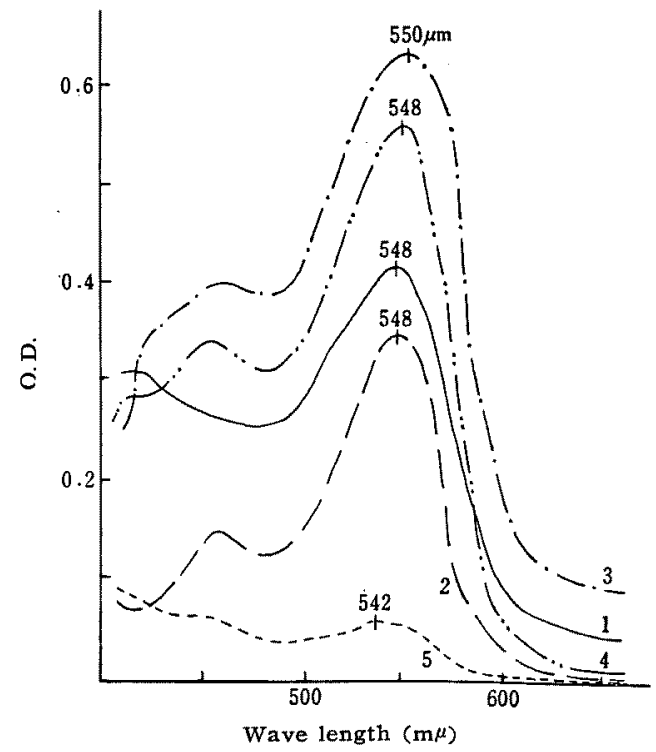

Fig. 3. Visible Absorption Spectra of Color formed by the HCl-Isoamyl Alcohol Reaction from Each Fraction. 


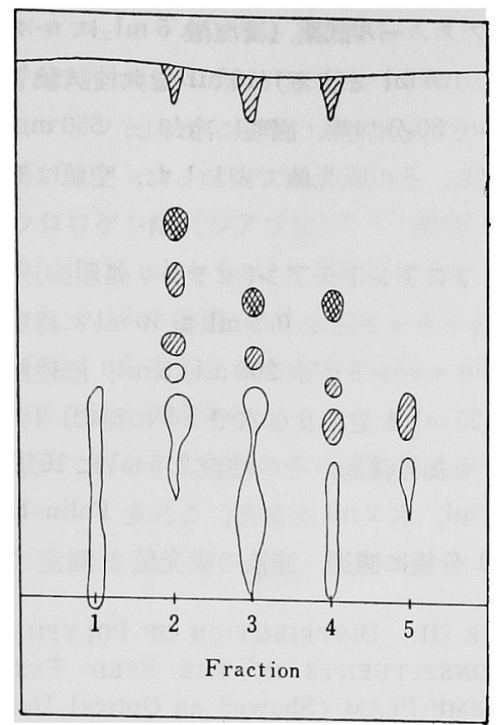

Fig. 4. Paper Chromatograms of Polyphenolic Constituents of Each Fraction.

Solvent : $n$-Butanol-acetic acid-water $(4: 1: 2)$

Blue spot with $\mathrm{FeCl}_{3}$ reagent
Brown spot with $\mathrm{FeCl}_{3}$ reagent Catechins

Brown spot with $\mathrm{FeCl}_{3}$ reagent
Pink spot with $\mathrm{HCl}$-vanilin reagent.

leucoanthocyanins

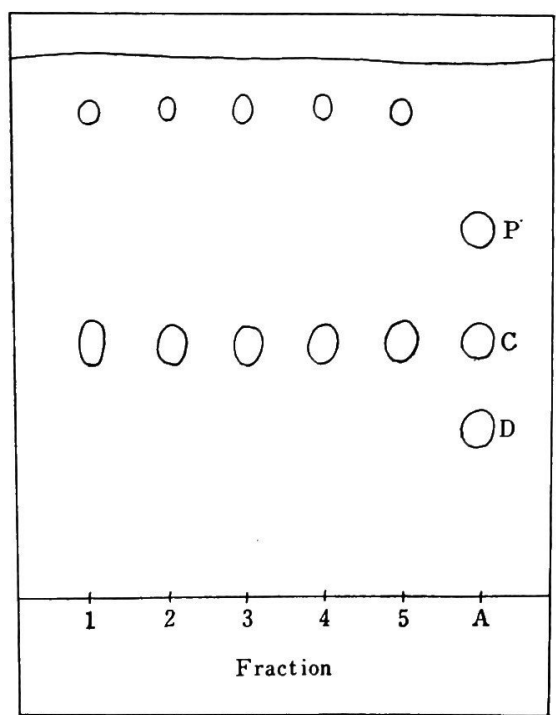

Fig. 5. Paper Chromatograms of Anthocyanidins yielded from Leucoanthocyanins in Each Fraction by the HCl-Isoamyl Alcohol Reaction.

A : Authentic anthocyanidins (chloride)
D, Delphinidin
C, Cyanidin

P, Pelargonidin

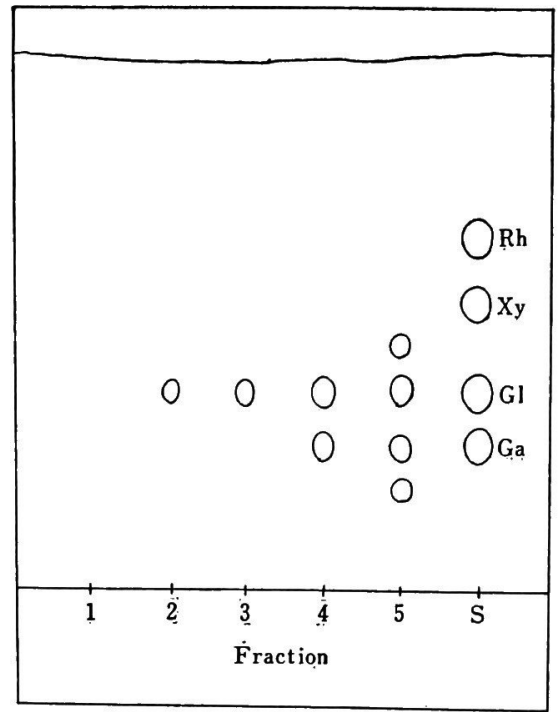

Fig. 6. Paper Chromatograms of the Component Sugars of Each Fraction.

$S$ : Authentic monosaccharides

$\mathrm{Rh}$, Rhamnose $\mathrm{Xy}, \mathrm{Xylose}$

G1, Glucose Ga, Galactose

に, さらに, 塩酸一イアミルアルコール反応によって 生成するアントシアニジン (イソァミルアルコール㬝の 濃縮物）の種類を, また加水分解によって生成する構成 糖の種類を, 以下に述べるペーパークロマトグラフ法に よって検索した.

i ）ポリフェノール成分の検出: 濾紙; 東洋 No. 50 , $40 \times 20 \mathrm{~cm}$. 展開剂; $n$-ブタノール-酢酸一水 $(4: 1: 2)$, 酢酸一塩酸一水 $(5: 1.5: 7)$. スポットの検出; $1 \%$ 塩化 第二鉄エタノール液, 紫外線ランプ, フェリシアン化カ リー鉄明ハン液, ハニリン一塩酸液, パラニトロアニリン 試薬. 得られた結果をまとめて Fig. 4 に示した.

ii）アントシアニジンの検出：展開剤；酢酸一塩酸-水 $(30: 3: 10)$, 発色剂は用いず, 赤色のスポットを標品 と比較した. 結果は Fig. 5 のよ5で, どのフラクショ ンからもシアニジンが検出された.

iii）構成糖の検出 : 各フラクション濃縮物を $1 \%$ 硫酸 で $100^{\circ}, 2$ 時間加水分解し, 生成する赤色色素をイソア ミルアルコールに転溶させてから, 水解液は炭酸カルシ ウム末で中和し，さらに 10\% 酢酸鉛液で不純物除去を 行ない, 硫化水素で脱鉛後, 滤液を濃縮したシラップに ついてペーパークロマトグラフ法を実施した，展開剤； $n$-ブタノール-酢酸-水 $(4: 1: 2)$ による上昇多重展開 
法. 発色剂; アニリンフタール酸試薬とフロログルシン 程酸試薬. 得られた結果は Fig. 6 のようである.

\section{4. ポリフェノール成分の分別定睹}

現在のところ，各種ポリフェノールの分別定量法は確 立されていないので，正確な含有量の測定は困難である が，定量的な Fig. 1 の分別法に従って得られる各フラ タション(租皮粉 $200 \mathrm{~g} \rightarrow 40 \mathrm{ml}$ ) について以下の定量法 至試み，各フェノール成分の分布状況を探索した。

(1) 全ポリフェノール (Folin-Denis 法 $)^{(4)}$ : 挨液 $5 \mathrm{ml}$ (各フラクション0.5 mlを $5 \mathrm{ml}$ に稀採) K Folin 詎薬（タングステン酸ソーダ $25 \mathrm{~g} ，$ リンモリブデン酸 5 $\mathrm{g}$, リン酸 $12.5 \mathrm{ml}$, 水 $188 \mathrm{ml}$ を 2 時間䞨沸後水で 11 とする） $5 \mathrm{ml}$ を加之， 3 分後に $10 \%$ 炭酸ソーが放 $5 \mathrm{ml}$ を混合し，1時間後に $700 \mathrm{m \mu}, 1 \mathrm{~cm}$ せルで剆定し，そ の吸光值 $(E)$ で表わした。空值は水 $5 \mathrm{ml}$ を同様に処理 したもの.

(2) フラパール, フラパンジオール（バニリン・

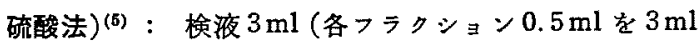
火稀释) にバニリン試薬（バニリン $1 \mathrm{~g} / 70 \%$ 硫酸 100 ml) $6 \mathrm{ml}$ を水冷下に加点, 室温 15 分後に $500 \mathrm{~m} \mu, 1$ $\mathrm{cm}$ 七ルで測定し，その吸光值で表わした．空値は検液 に70\%硫酸添加扎よび水にハンンンン試薬添加したもの.

(3) ロイコアントジン (塩酸・ブタノール法 $)^{(6)}$ : 険液 $1 \mathrm{ml}$ (各フラクション $0.5 \mathrm{ml}$ を $1 \mathrm{ml}$ K稀釈) と 塩酸-nーブタノール試薬（濃塩酸 $5 \mathrm{ml}$ に $n$-ブタノール を加えて $100 \mathrm{ml}$ とする) $10 \mathrm{ml}$ を共栓試験管にとり， 沸勝水中で 30 分加熱，直らに冷却し，550 $\mathrm{m} \mu, 1 \mathrm{~cm}$ 七 ルで测定し，その吸光値で表わした，空値は加熱しない 混液.

(4) プロアントシアン(ゼラチン処理法) ${ }^{(7)}$ : 検液 $10 \mathrm{ml}$ (各フラクション0.5 $\mathrm{ml} 10 \mathrm{ml}$ に稀釈) にゼラ チン液 (ビラチン $5 \mathrm{~g} /$ 水 $200 \mathrm{ml}$ ) $5 \mathrm{ml}$, 酸性飽和食塩水

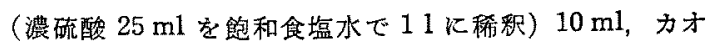
リン $1 \mathrm{~g}$ を加立濾過，その溜液 $2.5 \mathrm{ml}$ に $10 \%$ 炭酸ソー ダ液 $0.5 \mathrm{ml}$ ，水 $2 \mathrm{ml}$ を加え，これをFolin-Denis 法て 発色， 30 分後に濾過，濾液の吸光值を測定する.これ

TABlE III. Distribution OF POLYPhenOLIC Constituents in the Seed Testa of HEMP-PlaM (Showed as Optical Density)

\begin{tabular}{|c|c|c|c|c|}
\hline & \multicolumn{4}{|c|}{ Fraction } \\
\hline & 2 & 3 & 4 & 5 \\
\hline Total polyphenol*1 & 0.54 & 0.55 & 0.25 & 0.08 \\
\hline Flavanol Flavandiol $* 2$ & 0.36 & 0.15 & 0.09 & 0.05 \\
\hline Leucoanthocyanin*3 & 0.03 & 0.58 & 0.23 & 0.09 \\
\hline Proanthocyanin*4 & 0.41 & 0.50 & 0.21 & 0.08 \\
\hline Chlorogenic acid*5 & 0.38 & 0.48 & 0.23 & 0.05 \\
\hline $\begin{array}{ll}* 1 & \text { Folin-Denis method } \\
* 2 & \text { Vanillin } \mathrm{H}_{2} \mathrm{SO}_{4} \text { meth } \\
* 3 & \text { HCl- } n \text {-Butanol meth } \\
* 4 & \text { Gelatin treatment m } \\
* 5 & \text { Diazo method (8) }\end{array}$ & $\begin{array}{l}\text { (5) } \\
\text { (8) } \\
\operatorname{hod}^{(7)}\end{array}$ & & & \\
\hline
\end{tabular}

Table IV. Properties of leucoanthocyanins Isolated from the Seed Testa OF HEMP-PLAM

\begin{tabular}{|c|c|c|c|}
\hline Property & L-1 & $L-3$ & $\mathrm{~L}-4$ \\
\hline $\begin{array}{l}\text { Solubility } \\
\text { Methanol, Ethanol } \\
\text { Water, n-Butanol } \\
\text { Ethyl acetate } \\
\text { Acetic acid, Formic acid } \\
\text { Acetone, Ethyl ether, Chloroform }\end{array}$ & $\begin{array}{l}\text { easy soluble } \\
\text { soluble } \\
\text { insoluble } \\
\text { insoluble } \\
\text { insoluble }\end{array}$ & $\begin{array}{l}\text { easy soluble } \\
\text { soluble } \\
\text { soluble } \\
\text { hard soluble } \\
\text { insoluble }\end{array}$ & $\begin{array}{l}\text { easy soluble } \\
\text { soluble } \\
\text { hard soluble } \\
\text { hard soluble } \\
\text { insoluble }\end{array}$ \\
\hline $\begin{array}{l}\text { Detection } \\
\mathrm{NaOH} \text { solution } \\
\mathrm{FeCl}_{3} \text { solution } \\
\text { Diazo reagent } \\
\mathrm{HCl} \text {-isoamyl alcohol reaction } \\
\text { Vanillin- } \mathrm{HCl} \text { reaction } \\
\mathrm{Zn}-\mathrm{HCl} \text { reaction } \\
\mathrm{Mg}-\mathrm{HCl} \text { reaction }\end{array}$ & $\begin{array}{l}\text { dark brown } \\
\text { green } \\
\text { yellowish brown } \\
\text { strong positive } \\
\text { strong positive } \\
\text { negative } \\
\text { negative }\end{array}$ & $\begin{array}{l}\text { dark brown } \\
\quad \text { brown } \\
\text { yellowish brown } \\
\text { strong positive } \\
\text { positive } \\
\text { negative } \\
\text { negative }\end{array}$ & $\begin{array}{l}\text { dark brown } \\
\text { brown } \\
\text { yellowish brown } \\
\text { positive } \\
\text { positive } \\
\text { negative } \\
\text { negative }\end{array}$ \\
\hline $\begin{array}{l}\text { m.p. (decomp. }) \\
{[\alpha]_{\mathrm{D}}^{2 b}(c=1, \text { methanol })} \\
R_{F} \text { value* }\end{array}$ & $\begin{array}{c}>325^{\circ} \mathrm{C} \\
+46.9^{\circ} \\
\text { tailing } 0.00\end{array}$ & $\begin{array}{c}>251^{\circ} \mathrm{C} \\
+138.4^{\circ} \\
\text { tailing } 0 \sim 0.15\end{array}$ & $\begin{array}{c}>218^{\circ} \mathrm{C} \\
+86.1^{\circ} \\
\text { tailing } 0 \sim 0.23\end{array}$ \\
\hline
\end{tabular}

* Solvent systems : $n$-Butanol-acetic acid-water $(4: 1: 2)$; Acetic acid-hydrochloric acid-water $(5: 1.5: 7)$. 
が选離のポリフェノールとなる、ただしクロロゲン酸は $94 \%$ が, カテキンは $61 \%$ が残留しているから補正す る. 全ポリフェノールから旗離のポリフェノールを差引 いたものがプロアントシアンである。

(5) クロロゲン酸 (ジアソ法) $)^{(8)}$ : 検液 $5 \mathrm{ml}$ (各 フラクション $0.25 \mathrm{ml}$ を $5 \mathrm{ml}$ に稀䐆) に $1 \%$ 亜硝酸》 一ダ液 $2 \mathrm{ml} ， 0.15 \mathrm{~N}$-酶酸 $2 \mathrm{ml}$ を加之，5分後に $1 \mathrm{~N}-$ か性ソーダ液 $1 \mathrm{ml}$ 学加党水冷水中に保ち，530 $\mathrm{m}_{\mu, 1} 1$ $\mathrm{cm}$ セルで吸光值测定寸る。

以上の方法で得られた結果を, 便宜上吸光值で Table IIIに示した.

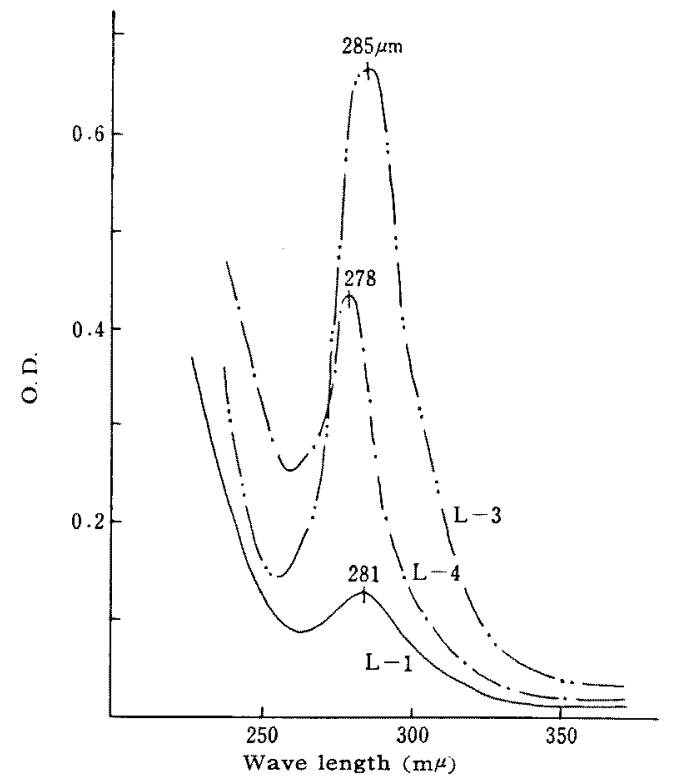

Fig. 7. UV-Absorption Spectra of Leucoanthocyanins isolated from the Seed Testa of Hemp-Plam.

TABLE V. UV-ABSORPTION PEAKS of POLYPHENOLIC COMPOUNDS

\begin{tabular}{ccc}
\hline Polyphenols & $\lambda_{\max }$ & $\lambda_{\text {rnin }}$ \\
\hline From Hemp-Plam & & \\
L-1 & $281 \mathrm{~m} \mu$ & $262 \mathrm{~m} \mu$ \\
L-3 & 285 & 249 \\
L-4 & 278 & 253 \\
\hline Authentic polyphenols & & \\
Kaki-tannin( 9 ) & 226,277 & 258 \\
Leucocyanidin & 285 & - \\
Leucodelphinidin & 282 & 250 \\
(-)-Epigallocatechin & 230,271 & 256 \\
Pyrogallol & 278 & - \\
Gallic acid & 266 & - \\
\hline
\end{tabular}

5. ロイコアントシアニジンおよびその配糖体，重合 体

㦈酸一イソアミルアルコール反応が強暒性のフラタシ ョン 1，3，4 からロイコアントシアンを無定形粉末とし て調製し，それらの理化学性をしらベた。

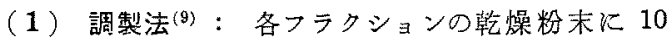
煷量のメタノール老加衣，沸点付近で 10 分間抽出して

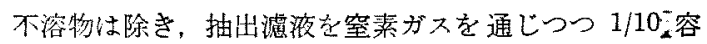

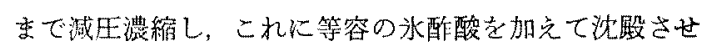
る。沈䟝は再びメタノールに溶解し, 減王濃縮後 5 倍容 の土チルェーテルを加えて沈殷させ，沈殿をェーテルで 洗浄, 真空乾燥してフラクション 1,3，4 からそれぞれ ロイコアントンアン L-1, L-3, L-4の淡色粉末を得た. 収率は乾燥種皮当りそれぞれ $2.96 \% ， 0.07 \% ， 0.61 \%$

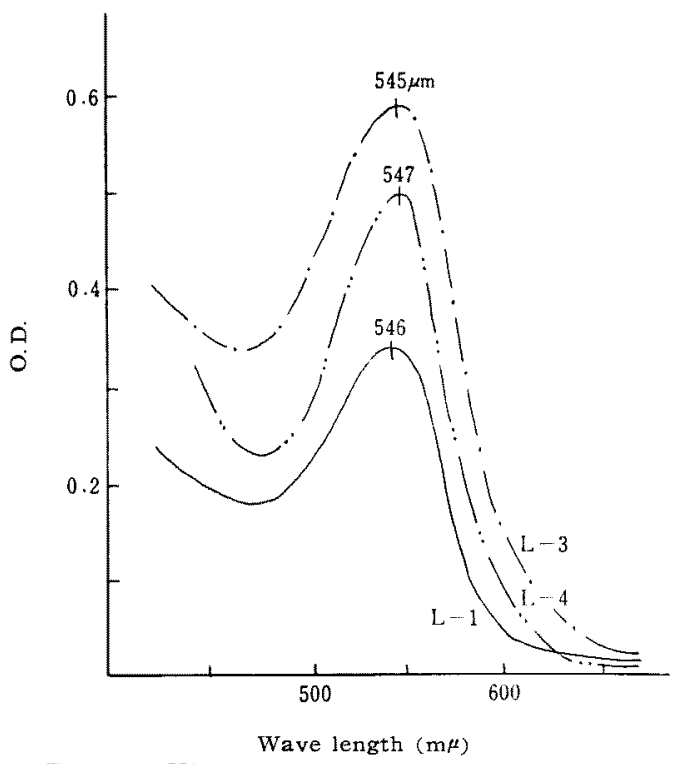

Fig. 8. Visible Absorption Spectra of Anthocyanidin yielded from the Hemp-Plam Leucoanthocyanins.

TABle VI. ABSorption PEAK of ANTHoCYANIDINS (CHLORIDE).

\begin{tabular}{ll}
\hline Anthocyanidin & $\lambda_{\max }$ \\
\hline From L-1 & $546 \mathrm{~m} \mu$ \\
From L-3 & 545 \\
From L-4 & 547 \\
\hline Delphinidin & 555 \\
Cyanidin & 545 \\
Pelargonidin & 530 \\
\hline
\end{tabular}




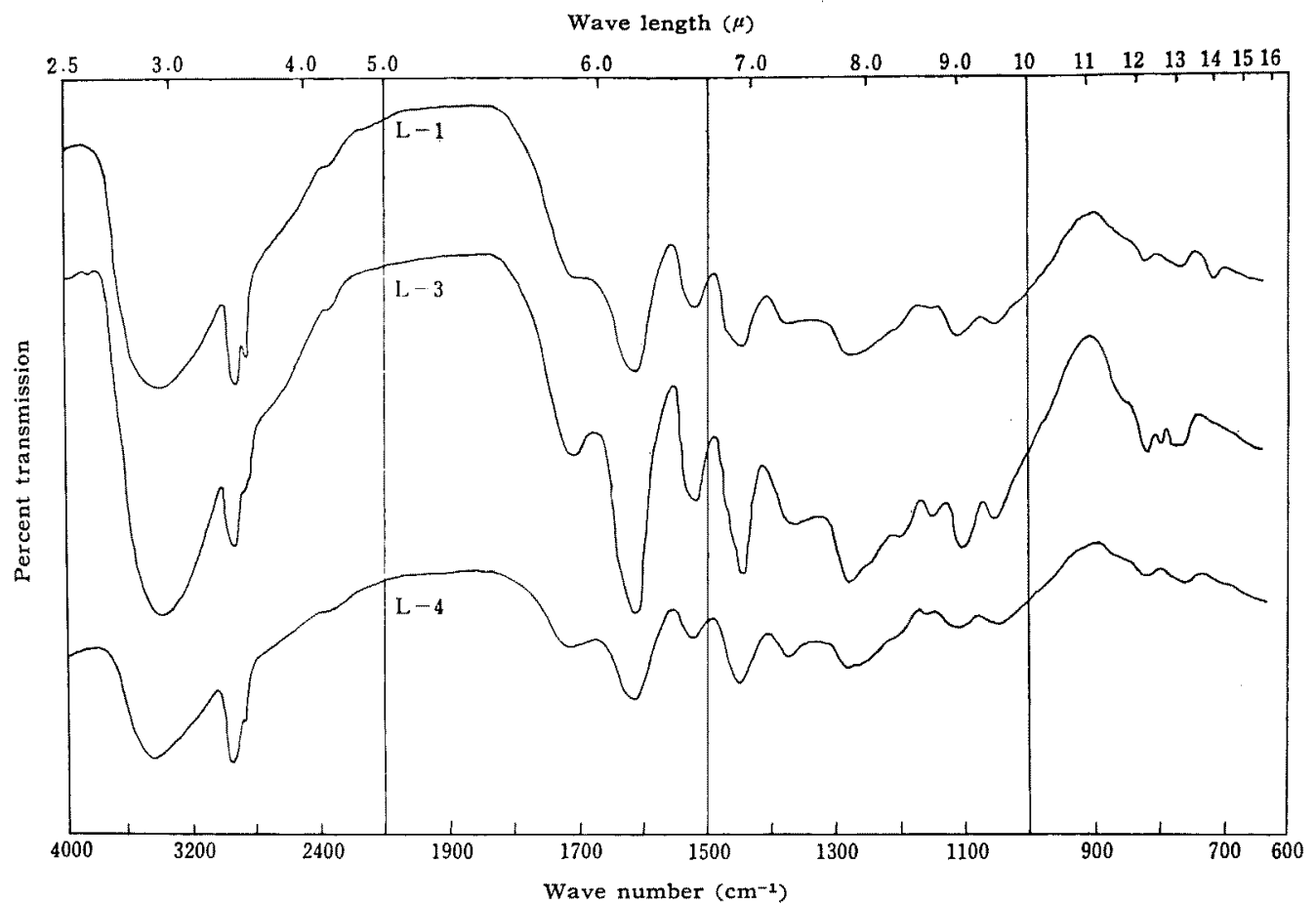

Fig. 9. Infrared Spectra of Leucoanthocyanins isolated from the Hemp-Plam Seed Testa.

であった。分離した粉末 $\mathrm{L}-1, \mathrm{~L}-3, \mathrm{~L}-4$ の物理性は Table IV のようである.

（2）紫外部吸収スペクトル：得られた L-1，L-3, L-4のメタノール溶液のスペクトルはFig. 7 の上 5 で, その吸収極大值を関連ポリフェノール類 ${ }^{(9)}$ と比較して Table V K示した。

(3) 可視部吸収スペクトル： L-1, L-3, L-4の粉 末について塩酸ーイソアミルアルコール反応(3)を行ない， 得られる赤色液の吸収スペクトルを测定し Fig. 8 を得 た。また，吸収極大を関連アントシアニジン ${ }^{(9)}$ 比較す れば Table VI のとおりである。

（4）赤外部吸収スペクトル：日本分光製赤外分光 器 IR-S 型によって, L-1, L-3， L-4 の IR-スペクトル を測定し Fig. 9 の結果を得た。測定は Prism NaCl, Suppression 5, Gain medium, Speed 10 による $\mathrm{KBr}$ 錠剂法 (KBr $200 \mathrm{mg}$ と試䊀 $1 \mathrm{mg}$ ).

（5）構成糖類：分離したシュ口種皮のロイコアン トシアン L-1，L-3，L-4 は，いずれも遊離の糖を全く 含んでいないことを予めぺーパークロマトグラフ法によ って確かめた後，50 倍量の $1 \mathrm{~N}$-硫酸で $100^{\circ}$ で 1 時間加 水分解し，イソアミルアルコールで数回抽出してアント
Table VII. Component Sugar of LeucoANTHOCYANINS ISOLATED FROM THE HEMP-PlaM SEED TESTA

\begin{tabular}{ccc}
\hline Leucoanthocyanin & Combined sugar & Content(\%) \\
\hline L-1 & none & - \\
L-3 & none & - \\
L-4 & glucose & $33.8^{*}$
\end{tabular}

* Calcd. for leucocyanidin mono-glucoside $\mathrm{C}_{21} \mathrm{H}_{24} \mathrm{O}_{12}$ : glucose $38.59 \%$.

TABle VIII. Degradation Products of LeucoANTHOCYANIN L-1, L-3 AND L-4.

\begin{tabular}{ccccc}
\hline $\begin{array}{c}\text { Leucoantho- } \\
\text { cyanin }\end{array}$ & $\begin{array}{c}\text { Antho- } \\
\text { cyanidin }\end{array}$ & $\begin{array}{c}\text { Phlobaphene } \\
\text { substances*1 }\end{array}$ & Catechins & Sugar \\
\hline L-1 & Cyanidin & 70.2 & $\begin{array}{l}\text { More than } \\
\text { three kinds*2 }\end{array}$ & none \\
L-3 & Cyanidin & 26.8 & none & none \\
L-4 & Cyanidin & 14.5 & none & glucose
\end{tabular}

*1 That was obtained as insoluble substances from hydrolysis solution with $2 \mathrm{~N}$-sulfuric acid at $100^{\circ} \mathrm{C}$ for $1 \mathrm{hr}$.

*2 Three catechins were presumed to be $(-)$-epicatechin, (-)-epicatechin gallate, $(+)$-catechin or gallic acid from the $R_{F}$ value and colors of their spot on paperchromatograms.

シアニジンを除去した水溶液を炭酸カルシウムで中和， さらに酢酸鉛処理して不純物除去，脱鉛後，滤液を濃縮 
TABLE IX. ACETyl DeRIVAtives of Leucoanthocyanin L-1, L-3 AND L-4

\begin{tabular}{ccccccc}
\hline $\begin{array}{c}\text { Leucoantho- } \\
\text { cyanin }\end{array}$ & $\begin{array}{c}\text { Yield } \\
(\%)\end{array}$ & Solubility & $\begin{array}{c}\mathrm{FeCl}_{3} \\
\text { reaction }\end{array}$ & $\begin{array}{c}{[\alpha]_{\mathrm{D}}^{21}} \\
(\mathrm{~A}) \\
\text { acetone }\end{array}$ & $\begin{array}{c}\mathrm{CH}_{3} \mathrm{CO} \\
(\%)\end{array}$ \\
\hline L-1 & 65.2 & insoluble & soluble & negative & $+50.7^{\circ}$ & 28.26 \\
$\mathrm{~L}-3$ & 48.7 & insoluble & soluble & negative & $+152.3^{\circ}$ & $40.78^{* 1}$ \\
$\mathrm{~L}-4$ & 70.9 & insoluble & soluble & negative & $+85.2^{\circ}$ & $44.54^{* 2}$
\end{tabular}

(A) Water, ethyl ether, ethanol etc.

(B) Acetone, chloroform, glacial acetic acid etc.

*1 Caled. for $\mathrm{C}_{15} \mathrm{H}_{8} \mathrm{O}_{7}\left(\mathrm{COCH}_{3}\right)_{8} ; \mathrm{CH}_{3} \mathrm{CO} 46.28 \%$.

*2 Calcd. for $\mathrm{C}_{21} \mathrm{H}_{14} \mathrm{O}_{12}\left(\mathrm{COCH}_{3}\right)_{10} ; \mathrm{CH}_{3} \mathrm{CO} 48.48 \%$.

したシラップについてペーパークロマトグラフ法を行な い，本解によって生成する糖の種類を検索した。 をた， ベルトラン法とソモギー法によって糖の定量を行なっ た. 結果を Table VII に示した。

（6）酸による分解痤物： L-1，L-3，L-4 をそれぞ れ 50 倍量の $2 \mathrm{~N}$-硫酸で $100^{\circ}, 1$ 時間分解し, 不溶性 残稙としてフロパフェン様物質を濾別秤量後, 濾液のイ ソアミルアルコール抽出物からシアニジンとカテキン類 を，また，炭酸カルシウムで中和した水層から糖類を， 前述のペーパークロマトグラフ法によって検索し Table VIII の結果を得た。

（7）アセチル化：シェ口種皮から分離した 3 種の ロイコアントシアンを 50 倍量の無水酢酸・ピリジン混 液 $(2: 1 \mathrm{v} / \mathrm{v})$ で，40で 72 時間アセチル化し，エチル エーテル・エタノール混液 $(1: 1 \mathrm{v} / \mathrm{v})$ で沈殿させて， 淡色のアセチル化物安得た。卆の理化学性を Table IX に毫とめた。

\section{考察}

シュロ種子(とくに種皮部) は塩酸-イソアミルアルコ 一ル反応が強陽性でロイコアントシアンの存在を知。 た、そこでまず，熱 $80 \%$ エタノールによって全ポリフ ェノ一ル成分を抽出し，抽出腋からェタノ一ルを留去 し，さらに食塩飽和による塩析によって縮合型重合体を 沈殿（フラクション1）として分別し，支の濾淮をさら にエチルエーテル，酢酸エチル，n-ブタノールで順次完 全に抽出することによってポリフェノール成分の分画を 行ない, Fig. 1 に示すようにフラタション 2, 3,4,5 とした，得られた各フラクションの濃縮物について定性 反応，紫外部，可視部吸収スペクトルならびにペーパー クロマトグラフ法による検索を行なった結果, フラクシ ョン $1,3,4$ Kロイコアントシアン含有量がとくに高 く、ロイコシアニジンを主体としていることが判明し
た.そこで、これら 3 このラクシ ョン濃縮物からロイコアントシアン の調製純化を行ない，それぞれ口イ コアントシアン L-1, L-3, L-4 を 無定形粉末として分離した。これら の理化学性と紫外, 可視, 赤外の 3 部吸収スペクトルをしらベるととも に，酸による分解産物，構成糖など を検索し，さらにア七チル誘導体を 調製した。

以上の結果は，L-1はロイコシアニジンのカテキン類 【おてらく（一)-エピカテキン（一)ーエピカテキンガレ

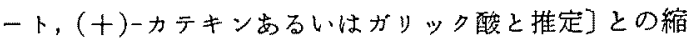
合型重合体，L-3 は口イコシアニジンあるいはそのオリ ゴマー，L-4 はロイコシアニジンのモノグルコシドであ ることを示している.したがって、シュ口種子中のトイ コアントシアンはロイコシアニジンから成り，縮合型 (ホモまたはへテロのポリマーあるいはオリゴマーとし て), 遊離型, 配糖体型の 3 形態が混在して分布するる のと思考される。<smiles>CC(O)C1Oc2cc(O)ccc2C(C)C1c1ccc(O)c(O)c1</smiles>
Hô म्́ OH

Leucocyanidin (Monomer type), L-3

-O-Leucocyanidin (Oligomer type), L-3

-O-Catechins (Hetero-polymer type), L-1 -O-Glucose (Glucoside type), L-4 [Colorless]

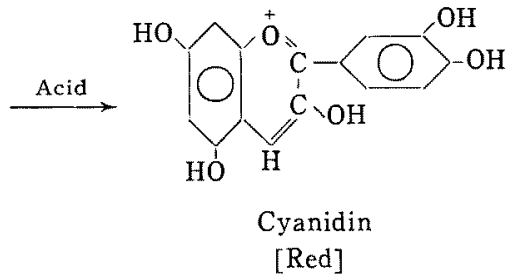

Leucoanthocyanins of the Hemp-Plam Seed

$$
\text { 要 約 }
$$

（1）シュ口種子(種皮部) のポリフェノール成分を 5つのフラクションに分別 (Fig. 1)，それらの理化学性 を㛟索したところ (Fig. 2〜6, Table II, III)，フラク 
ショソ 1, 3, 4 にロイコシアニジンを主体とするロイコ アントシアンの存在を知った。

(2) そこで, フラクション 1，3，4 からそれぞれ口 イコアントシアン L-1，L-3，L-4 を分別単離し，検索 した結果，いずれもロイコシアニジンを主棈成分とし，

L-1 てはカテキン類との縮合型重合体，L-3 は游離型志 るいはオリゴマー体，L-4では配粕体（モグルニンド） であることがわかった（Fig. 7〜9， Table IV〜IX).

終りに，標品をいただき御教示くださった本学 中林 敏郎博士，赤外スペクトルを測定くださった甲悲罗二氏， 紫外・可視スペクトル湘定さ担当された小田喜一郎氏に 深く感謝いたします。

なお, 本研究の大要は昭和 42 年 6 月 3 日, 日本留芸 化学会中部支部第 42 回例会に怙いて講演した。
（1）平尾子之吉：日本植物成分総覽，第 3 巻， p. 454 . 传↔木書店，1956.

（2）水野 龺：食品工誌, 11, 100 (1964).

(3) E.C. Bate-Smith : Biochem. J., 58, 122, 126 (1954).

(4) O. Folin, W.Denis : J. Biol. Chem., 22, 305 (1915).

(5) J. I. Goldstein, T.Swain: Nature, 198, 587 (1963).

(6) T. Swain, W. E. Hills: J. Sci. Food Agr., 10, 135 (1959).

(7) 中林敏郎: 未発考。

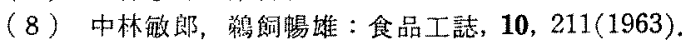

（9）伊藤三郎：園芸試臨場報告，B-1，1（1962）; 食品工誌, 12, 295 (1965); Nature, 204, 475 (1964).

(10) E. Haslam : "Chem. of Vegelable Tannins", Academic Press, 1966, p. 58, 78, 80. 